\title{
Korelasi Antara Push dan Pull Factor Wisata Kawasan dan Bangunan Bersejarah
}

\author{
Charlie Lady Beauty Afriesta ${ }^{1}$, Hanson E. Kurniawan ${ }^{2}$, Sri Nastiti N. \\ Ekasiwi $^{3}$
}

\author{
Affiliation \\ ${ }^{1}$ Program Studi Magister Rancang Kota, SAPPK, Institut Teknologi Bandung; ${ }^{2}$ Kelompok \\ Keilmuan Perancangan Arsitektur, SAPPK, Institut Teknologi Bandung; ${ }^{3}$ Departemen \\ Arsitektur, Institut Teknologi Sepuluh November Surabaya
}

\section{Correspondence}

Charlie Lady Beauty Afriesta. Program Studi Magister Rancang Kota, Sekolah Arsitektur, Perencanaan, dan Pengembangan Kebijakan (SAPPK), Institut Teknologi Bandung. JI. B, Lb. Siliwangi, Kecamatan Coblong, Kota Bandung, Jawa Barat 40132. Email:

charlie.lady@students.itb.ac.id

\begin{abstract}
Historical areas and buildings are one of the tourist destinations visited by the community. People have several reasons for visiting historical areas and buildings. There are two factors, push and pull, in visiting historical areas and buildings. The push factor is a driving factor which is a person's motivation. While the pull factor is an environmental factor that attracts a person in traveling. The purpose of this research is to find the push and pull factors in visiting historical areas and buildings, and to see the correlation of these two factors. From the analysis, it is found that there are three dimensions of push, namely educational, physiological, and interpersonal; and four pull dimensions, namely accessibility and affordability, environmental quality, and experience, social, and object attractiveness. The educational dimension has a high correlation with object attractiveness. The interpersonal dimension has a high correlation with the social dimension, and the physiological dimension has a high correlation with the quality of the environment and experiences.
\end{abstract}

Keywords: Historical buildings; Historical areas; Push and pull factors; Travel motivation.

Article Information

Submitted 21 May 2019 | Revised 13 December 2019 | Accepted 3 September 2020

Recommended Citation: Afriesta, C. L. B., Kurniawan, H. E., and Ekasiwi, S. N. N. (2020). Korelasi Antara Push dan Pull Factor Wisata Kawasan dan Bangunan Bersejarah. Jurnal Pariwisata Terapan, 4(1), 1-11. https://doi.org/10.22146/jpt.46036 


\section{Pendahuluan}

Objek dari wisata sejarah dapat berupa sumber daya baik itu tidak berwujud (intangible) dan terwujud (tangible) dari masa lalu. Sumber daya tidak berwujud mencakup musik, tarian, bahasa, agama, makanan, dan tradisi. Sedangkan yang berwujud adalah bangunan bersejarah, museum, relik arkeologi, kastil, katedral (Timothy, 2009). Setiap objek wisata akan mendatangkan pengunjung dengan berbagai motivasi yang berbeda.

Banyak studi yang menjelaskan peran kawasan dan bangunan bersejarah terhadap naiknya sektor wisata. Menurut Assiouras (2015), budaya dan warisan objek sejarah merupakan salah satu faktor penarik dalam mendatangkan wisatawan. Warisan objek sejarah merupakan hal yang penting bagi pariwisata, karena dapat memicu motivasi wisatawan dan menjadi dasar bagi layanan industri. Aktivitas wisatawan akan menyediakan lapangan pekerjaan bagi penduduk lokal yang dapat memutar roda perekonomian. Henderson (2009) juga mengungkapkan bahwa sebuah objek sejarah akan mampu mempengaruhi ekonomi, nilai sosial, dan politik baik itu bagi wisatawan maupun penduduk sekitar.

Peran penduduk lokal dan wisatawan yang datang pun akan menaikan antusias tentang warisan objek bersejarah. Naiknya sektor ekonomi merupakan alasan pemerintah dalam turut andil menjaga kawasan dan bangunan bersejarah. Dengan munculnya obyek wisata baru, tingkat ekonomi masyarakat akan meningkat. Dengan begitu pemerintah pun turut andil dalam mendukung salah satu fenomena ini. Salah satu caranya adalah dengan menjaga keutuhan kawasan dan bangungan bersejarah. Upaya yang dilakukan pemerintah meliputi tindakan-tindakan preventif, represif, maupun kuratif (Widiastuti, 2014).

Kegandrungan masyarakat dalam melakukan wisata bersejarah cukup tinggi. Perjalanan wisata pun biasanya mencakup skala yang luas dari warisan budaya, pusat kota bersejarah, museum, taman bersejarah, hingga kawasan dan bangunan bersejarah. Pesona dan wisata yang ditawarkan oleh kawasan bersejarah membuat masyarakat berwisata ke kawasan dan bangunan bersejarah. Kegemaran ini ternyata juga karena adanya kecenderungan masyarakat untuk mencari hal yang unik dan autentik dari suatu kebudayaan (Suarmana, 2017).

Pengunjung wisata cenderung memiliki motivasi mencari pengalaman baik dari segi pendidikan, visual, dan rekreasi serta kenangan yang ditawarkan oleh aset bersejarah (Susana, 2002). Motivasi menurut Mitchell dalam Hayani (2007: 15) mewakili proses-proses psikologikal, yang menyebabkan timbulnya, diarahkannya, dan terjadinya persistensi kegiatan-kegiatan sukarela yang diarahkan ke arah tujuan tertentu. Crompton (1979) menjelaskan bahwa motivasi perjalanan dipengaruhi oleh dua faktor yaitu pendorong (push) dan penarik (pull). Faktor pendorong merupakan faktor yang berasal dari diri manusia atau biasa disebut sebagai motivasi. Sedangkan faktor penarik merupakan faktor yang berasal dari lingkungan tempat wisata.

Masyarakat memiliki beragam motivasi dalam melakukan pariwisata, begitu pula dalam mengunjungi kawasan dan bangunan bersejarah. Mclntosh (1977), Murphy (1985) dan Sharpley (1994) dalam Fitria Sari (2014: 4-5) menjelaskan ada 4 motivasi seseorang dalam mengunjungi tempat wisata atau tempat baru, yaitu: 


\section{Physical or physiological motivation}

Motivasi ini antara lain untuk relaksasi, kesehatan, kenyamanan, bersantai, dan sebagainya.

2. Cultural motivation

Motivasi budaya yaitu keinginan dalam mengetahui budaya, adat, tradisi daerah lain.

3. Social motivation (interpersonal motivation)

Motivasi sosial adalah motivasi yang bersifat hubungan yaitu mengunjungi teman, keluarga, melakukan hal yang bersifat prestise, ziarah, dan lain-lain.

4. Fantasy motivation

Motivasi ini dilandaskan pada fantasi dan keinginan seseorang dalam lepas dari rutinitas yang menjemukan.

Sedangkan dalam studi lain, Oka Yoeti dalam dalam Hayani (2007: 16) menjelaskan ada 4 kategori motivasi untuk berpariwisata dapat dibagi ke dalam empat kategori, yaitu:

1. Pendidikan

Keinginan melihat tempat bersejarah, menambah pengetahuan, dan keinginan berpartisipasi dalam suatu festival budaya merupakan alasan pendidikan dalam bepergian atau pariwisata.

2. Hiburan

Motivasi hiburan adalah keinginan untuk lepas dari kesibukan sehari-hari, dan mendapatkan suasana baru.

3. Kesehatan

Olahraga, menghilangkan ketegangan pikiran dan relaksasi merupakan motivasi kesehatan dalam mengunjungi tempat wisata.

4. Bisnis

Alasan bisnis adalah dengan menghadiri konferensi, seminar, ikut kegiatan sosial, dan lain-lain.

Faktor yang mempengaruhi seseorang juga dari faktor lingkungan. Faktor lingkungan merupakan faktor penarik bagi wisatawan. Menurut Baloglu \& Uysal (1996) dalam Mohammad (2010) faktor penarik sebaliknya adalah yang muncul sebagai daya tarik tujuan yang dianggap menarik oleh wisatawan. Faktor ini mencakup persepsi dan harapan para wisatawan seperti hal yang baru dan citra pariwisata. Crompton (1979) dalam Mohammad (2010), mencoba untuk menarik 7 motif sosio-psikologis atau dorongan (push faktor) yaitu escape, self-exploratory, relaxation, prestige, regression, kinship-enhancement, dan social interaction. Sedangkan faktor penarik adalah novelty dan education.

Penelitian ini bertujuan mengungkap dimensi motivasi internal (push) dan faktor lingkungan eksternal (pull) yang muncul dalam wisatawan ketika mengunjungi kawasan dan bangunan bersejarah, serta korelasi dari keduanya. Pengetahuan tentang motivasi dan faktor lingkungan, serta hubungannya diharapkan dapat digunakan untuk memprediksi pola perjalanan kawasan dan bangunan bersejarah di masa depan. 


\section{Metode}

Metode penelitian ini menggunakan metode kuantitatif yang bersifat eksploratif dan juga eksplanatori (Creswell, 2008; Groat \& Wang, 2002). Pada penelitian ini akan diungkapkan dimensi push dan pull dalam mengunjungi kawsan dan bangunan bersejarah, serta korelasi dari kedua faktor tersebut.

Pengumpulan data dilakukan dengan kuesioner yang disebarkan secara daring (online). Kuesioner dibagikan dengan cara snowball-non-random-sampling. Sifat dari pertanyaan adalah close-ended question. Data yang dikumpulkan berupa data numerik yang nantinya diolah secara kuantitatif.

Kerangka pertanyaan didapat dari penelitian sebelum ini mengenai hubungan pengetahuan masyarakat dengan motivasi melakukan wisata sejarah. Dari penelitian tersebut digolongkan adanya 2 faktor yaitu faktor penarik (pull) dan faktor pendorong (push). Total responden yang didapat adalah 119 responden, dengan 63 orang berasal dari Malang, dan 56 orang berasal dari luar malang (lihat diagram 1). Responden terdiri dari 65 orang berjenis kelamin laki-laki, dan 54 perempuan. Responden didominasi dari usia 17-25 tahun sebesar 68 orang, dan 50 orang berusia lebih dari 25 tahun. Pekerjaan dibagi berdasarkan pelajar, pegawai negeri, pegawai swasta, wiraswasta, dan lain-lain. Responden terbanyak adalah swasta dengan 56 orang.

Dalam kuesioner ini, responden diminta untuk menilai faktor-faktor terkait kunjungan ke kawasan dan bangunan bersejarah. Pertanyaan disusun menggunakan jawaban dengan skala likert, berskala 1 sampai dengan 6. Contoh pertanyaan dalam kuisoner online diperlihatkan pada Tabel 1. Dari hasil kuesioner diperoleh data numerik, yang akan dianalisis secara kuantitatif. Data akan diolah dengan menggunakan metode analisis faktor. Setelah mendapat hasil dari push dan pull faktor dalam mengunjungi kawasan dan bangunan bersejarah, maka selanjutnya dilihat korelasi antar kedua faktor tersebut.

Tabel 1. Contoh Pertanyaan Berskala Likert

\begin{tabular}{ccc}
\hline Sangat tidak setuju & 123456 & Sangat setuju \\
\hline Sangat tidak penting & 123456 & Sangat penting \\
\hline
\end{tabular}

(Sumber: Analisis Peneliti, 2018)

\section{Hasil dan Pembahasan}

Hasil analisis faktor motivasi ditampilkan dalam Tabel 2. Ditemukan tiga variabel laten/dimensi yang dianggap sudah mampu mempresentasikan motivasi internal. Ketiga dimensi tersebut adalah edukasi, interpersonal, dan fisiologis. 
Tabel 2. Faktor/Variabel Laten Motivasi Internal Hasil Faktor Analisis

\begin{tabular}{cccc}
\hline & Edukasi & Interpersonal & Fisiologis \\
\hline Mendapatkan hal baru & 0,88 & 0,00 & 0,10 \\
\hline Pengetahuan budaya Indonesia & 0,84 & 0,24 & 0,04 \\
\hline Pengetahuan sejarah akan kota & 0,78 & 0,24 & $-0,05$ \\
\hline Suka sejarah & 0,74 & 0,03 & 0,17 \\
\hline Terlihat keren & $-0,17$ & 0,76 & 0,29 \\
\hline Acara rohani & 0,23 & 0,73 & 0,29 \\
\hline kontemplasi & 0,44 & 0,67 & $-0,15$ \\
\hline Aktifitas sejarah & 0,54 & 0,57 & $-0,04$ \\
\hline Melepaskan kepenatan & 0,27 & 0,06 & 0,82 \\
\hline Fotografi & $-0,08$ & 0,18 & 0,78
\end{tabular}

(Sumber: Analisis Peneliti, 2018)

Tabel 2 memperlihatkan adanya tiga dimensi wisatawan dalam mengunjungi bangunan dan kawasan bersejarah, yaitu:

1. Edukasi

Rasa keingintahuan merupakan dasar dari motivasi ini. Wisatawan mengunjungi bangunan dan kawasan bersejarah dikarenakan rasa ingin tahu atau ingin mempelajari hal baru, baik tentang pengetahuan budaya, sejarah kota, hingga keminatan akan mempelajari nilai sejarah.

2. Interpersonal

Motivasi ini berkaitan dengan rasa prestise dalam diri wisatawan. Wisatawan dengan motivasi ini cenderung hanya ingin memuaskan keinginan untuk berkontemplasi, mengikuti aktifitas sejarah, hingga acara rohani.

3. Fisiologis

Motivasi fisiologis berhubungan dengan kebutuhan wisatawan dalam melepaskan kepenatan serta kebutuhan fotografi. Biasanya wisatawan dengan motivasi ini cenderung mengunjungi kawasan dan bangunan sejarah karena alasan pribadi.

Ketiga motivasi internal yang muncul dapat dibandingkan dengan teori tentang motivasi perjalanan seseorang yang sebelumnya telah dibahas.

Physical atau physiological motivation memiliki kesamaan arti dengan motivasi kesehatan yang dikemukakan oleh Oka Yoeti. Kedua nya memiliki arti yang serupa yaitu berhubungan dengan relaksasi dan melepaskan kepenatan. Dalam hasil motivasi internal dalam mengunjungi kawasan dan bangunan bersejarah, motivasi fisiologis merupakan motivasi yang memiliki arti sangat dekat dengan keduanya. Poria, Butler \& Airey (2003) menjabarkan bahwa faktor pendorong dalam melakukan wisata sejarah salah satunya adalah relaksasi.

Motivasi fisiologis juga berkaitan dengan fantasy motivation oleh Mclntosh (1997) dan motivasi hiburan oleh Oka Yoeti. Fantasy motivation dan motivasi hiburan memiliki arti sebagai motivasi seseorang untuk lepas dari kesibukan sehar-hari dan mencari hal baru. Arti motivasi fisiologis sendiri adalah sebuah motivasi untuk lepas dari kepenatan. Salah satu cara dari menghilangkan tersebut adalah dengan mencari hal baru yang berbeda dari rutinitas sehari-hari. 
Motivasi edukasi merupakan motivasi yang didasari pada keingintahuan seseorang. Cultural motivation yang diutarakan oleh McIntosh (1977) dan motivasi pendidikan yang diutarakan oleh Oka Yoeti memiliki pengertian yang sama dengan motivasi edukasi pada penelitian ini. Wisatawan cenderung ingin mendapatkan hal baru dan pengetahuan akan hal yang mereka kunjungi. Pendidikan merupakan hal yang utama dalam wisata sejarah. Kawasan dan bangunan sejarah merupakan sarana yang paling baik dalam mengenal sejarah suatu negara (Widiastuti,2014).

Motivasi yang ketiga adalah motivasi interpersonal yang menjabarkan sebuah keinginan dalam memuaskan keinginan prestis seseorang dalam mengunjungi kawasan dan bangunan bersejarah. Motivasi ini sangat berdekatan arti dengan social motivation yang dijelaskan oleh McIntosh (1997). Social motivation sendiri merupakan motivasi yang terbentuk karena keinginan prestis dan rohani seseorang. Dalam push faktor wisata mengunjungi kawasan dan bangunan bersejarah, tidak ditemukan adanya motivasi karena keinginan seseorang dalam berbisnis seperti yang diungkapkan Oka Yoeti. Hal ini bisa disebabkan karena sangat jarang kawasan dan bangunan bersejarah dijadikan sebagai tempat temu seseorang dalam berbisnis, hingga mengadakan konferensi bisnis. Namun jika perkembangan wisata menuju kawasan dan bangunan bersejarah semakin tinggi, sangat memungkinkan akan memunculkan push faktor dari segi motivasi bisnis untuk mengunjungi kawasan dan bangunan bersejarah.

Tabel 3. Perbandingan Motivasi Dalam Literatur dan Hasil Analisis.

\begin{tabular}{|c|c|c|c|}
\hline $\begin{array}{c}\text { Mclntosh 1977, } \\
\text { Murphy } 1985 \text { dan } \\
\text { Sharpley } 1994 \text { dalam } \\
\text { Fitria Sari (2014: 4-5) }\end{array}$ & $\begin{array}{c}\text { Oka Yoeti dalam } \\
\text { dalam Hayani (2007: } \\
16)\end{array}$ & Crompton (1979) & Afriesta (2018) \\
\hline \multirow{2}{*}{$\begin{array}{l}\text { Physical or } \\
\text { physiological } \\
\text { motivation }\end{array}$} & \multirow[t]{2}{*}{ Kesehatan } & Escape & \multirow[t]{4}{*}{ Fisiologis } \\
\hline & & Relaxation & \\
\hline \multirow[t]{2}{*}{ Fantasy motivation } & \multirow[t]{2}{*}{ Hiburan } & Self-exploratory & \\
\hline & & Prestige & \\
\hline Cultural motivation & Pendidikan & - & Edukasi \\
\hline \multirow{3}{*}{$\begin{array}{l}\text { Social motivation } \\
\text { (interpersonal } \\
\text { motivation) }\end{array}$} & \multirow[t]{3}{*}{-} & Regression & \multirow[t]{3}{*}{ Interpersonal } \\
\hline & & Kinship-enhancement & \\
\hline & & Social interaction & \\
\hline- & Bisnis & - & - \\
\hline
\end{tabular}

Selanjutnya dari analisis faktor pull didapatkan empat variabel laten/dimensi seseorang dalam mengunjungi kawasan dan bangunan bersejarah, yaitu aksesibilitas dan keterjangkauan; kualitas lingkungan dan pengalaman; sosial; dan daya tarik objek. Pada Tabel 4, terlihat bagaimana setiap variable laten mewakili faktor eksternal dari pertanyaan kuisoner. 
Tabel 4. Variabel Laten/Dimensi Hasil Analisis Faktor

\begin{tabular}{|c|c|c|c|c|}
\hline & $\begin{array}{l}\text { Aksesibilitas dan } \\
\text { keterjangkauan }\end{array}$ & $\begin{array}{c}\text { Kualitas lingkungan } \\
\text { dan pengalaman }\end{array}$ & Sosial & Daya tarik objek \\
\hline Jaraknya dekat & 0,79 & 0,14 & 0,15 & 0,06 \\
\hline $\begin{array}{l}\text { Mudah ditempuh dan } \\
\text { nyaman }\end{array}$ & 0,76 & 0,11 & 0,21 & 0,32 \\
\hline Adanya kendaraan umum & 0,70 & 0,13 & 0,10 & 0,39 \\
\hline $\begin{array}{l}\text { Dekat dengan tempat } \\
\text { wisata lain }\end{array}$ & 0,69 & 0,18 & 0,36 & 0,04 \\
\hline Terkenal & 0,68 & 0,17 & $-0,04$ & 0,07 \\
\hline Fasilitas makan/minum & 0,64 & 0,27 & 0,29 & 0,15 \\
\hline Harga tiketnya murah & 0,59 & 0,29 & 0,30 & $-0,09$ \\
\hline Sakral & 0,11 & 0,80 & 0,03 & 0,18 \\
\hline Nuansa romantis & 0,17 & 0,76 & 0,24 & $-0,06$ \\
\hline Lingkungannya bersih & 0,29 & 0,65 & 0,19 & 0,28 \\
\hline $\begin{array}{l}\text { Adanya pengalaman } \\
\text { kebudayaan }\end{array}$ & 0,22 & 0,65 & 0,12 & 0,32 \\
\hline Acara yang menarik & 0,28 & 0,61 & 0,34 & $-0,02$ \\
\hline $\begin{array}{l}\text { Alasan pendidikan (tugas } \\
\text { sekolah) }\end{array}$ & 0,13 & 0,14 & 0,89 & 0,12 \\
\hline Tuntutan pekerjaan & 0,20 & 0,23 & 0,82 & 0,08 \\
\hline Ajakan teman/keluarga & 0,31 & 0,19 & 0,65 & $-0,05$ \\
\hline Bangunan yang unik & 0,18 & 0,35 & $-0,03$ & 0,83 \\
\hline $\begin{array}{l}\text { Keaslian arsitektural } \\
\text { bangunannya }\end{array}$ & 0,14 & 0,37 & $-0,14$ & 0,81 \\
\hline Fasilitas tour guide & 0,11 & $-0,16$ & 0,29 & 0,71 \\
\hline
\end{tabular}

(Sumber: Analisis Peneliti, 2018)

Empat dimensi mampu mewakili beragam faktor lingkungan kawasan dan bangunan bersejarah. Aksesibilitas dan keterjangkauan merupakan faktor pull yang seseorang lakukan dalam mengunjungi kawasan dan bangunan bersejarah. Aksesibilitas dan keterjangkauan mencakup jarak lokasi, kemudahan lokasi ditempuh, juga adanya kendaraan umum yang memadai yang memudahkan seseorang untuk mengunjungi kawasan dan bangunan bersejarah. Semakin satu kawasan dan bangunan bersejarah memiliki akses yang baik serta kemudahan dalam pencapaiannya, maka akan semakin besar pula wisatawan yang akan mengunjungi. Hal ini pun tidak terlepas dari fasilitas yang disediakan oleh tempat tersebut. Fasilitas makan dan minum serta harga tiket masuk ternyata menjadi penarik bagi seseorang untuk mengunjungi kawasan dan bangunan bersejarah.

Dimensi yang ke-dua adalah kualitas lingkungan dan pengalaman. Kualitas lingkungan dan pengalaman ini sangat erat hubungannya dengan suasana suatu kawasan. Biasanya merupakan harapan seseorang akan kualitas lingkungan. Dalam kasus ini beberapa responden menjelaskan bahwa suasana dari kawasan dan bangunan sejarah yang sakral, romantis, dan bersih merupakan penarik yang membuat mereka datang. Dalam hal ini tuntutan pekerjaan hingga ajakan orang terdekat sebagai alasan bepergian.

Dimensi pull yang berikutnya adalah sosial. Dimensi sosial di sini adalah penarik wisatawan menuju kawasan dan bangunan bersejarah karena lingkungan sosial. Lingkungan sosial yang dimaksud adalah karena ajakan keluarga, tugas sekolah hingga tugas kantor yang mewajibkan seseorang mengunjungi kawasan dan bangunan bersejarah. Dimensi yang 
terakhir adalah daya tarik objek. Daya tarik objek merupakan faktor yang diperhatikan seseorang dalam mengunjungi kawasan dan bangunan bersejarah. Ketertarikan seseorang akan suatu objek bersejarah tak lepas dari bentuk visual yang ditawarkan oleh kawasan dan bangunan bersejarah.

Dari analisis di atas, maka dihasilkan adanya tiga dimensi motivasi internal seseorang dalam mengunjungi kawasan dan bangunan sejarah, serta empat dimensi faktor lingkungan. Poria, Butler \& Airey (2003) menjabarkan bahwa motivasi, perilaku, dan persepsi berkaitan sangat erat dengan persepsi suatu kawasan. Dengan begitu, maka faktor pendorong seseorang akan sangat berkaitan dengan persepsi akan faktor penarik dalam mengunjungi kawasan dan bangunan bersejarah. Hasil dari analisis korelasi antara faktor pendorong dan faktor penarik dapat dilihat pada Tabel 5.

Tabel 5. Korelasi Antara Push dan Pull Faktor

\begin{tabular}{lcccc}
\hline & $\begin{array}{c}\text { Aksesibilitas dan } \\
\text { keterjangkauan }\end{array}$ & $\begin{array}{c}\text { Kualitas } \\
\text { lingkungan dan } \\
\text { pengalaman }\end{array}$ & Sosial & Daya tarik objek \\
\hline Edukasi & 0,1401 & 0,2666 & $-0,0952$ & 0,4156 \\
\hline Interpersonal & 0,2749 & 0,1132 & 0,3554 & $-0,0737$ \\
\hline Fisiologis & 0,2333 & 0,3853 & 0,1184 & 0,0285 \\
\hline \multicolumn{4}{c}{$* * \mathrm{p}<0,0001 ; * * \mathrm{p}<0,05$} \\
\hline
\end{tabular}

(Sumber: Analisis Peneliti, 2018)

Pada Tabel 5, dapat dilihat masing-masing faktor pendorong seseorang memiliki faktor penarik yang berbeda-beda dalam mengunjungi kawasan dan bangunan bersejarah. Seseorang dengan motivasi edukasi, akan mendatangi kawasan bersejarah karena daya tarik objek dan kualitas lingkungan serta pengalamannya. Hal yang pertama dicari saat seseorang dengan motivasi adalah keinginan untuk mencari pengetahuan baru dengan melihat daya tarik objek. Wisatawan ini datang bukan karena ajakan orang lain atau melihat kemudahan aksesibilitas. Mereka cenderung melihat potensi dan pengetahuan yang bisa didapat dalam mengunjungi kawasan dan bangunan sejarah.

Wisatawan dengan motivasi interpersonal justru seseorang yang bertolak belakang dengan mereka yang memiliki motivasi edukasi. Wisatawan dengan motivasi ini memiliki faktor penarik bukan melihat dari segi visual dan kualitas lingkungan, namun karena ajakan teman dan kemudahan aksesibilitas. Jika tidak ada ajakan teman atau urusan personal dan akses menuju kawasan dan bangunan bersejarah cukup sulit, sangat memungkinkan wisatawan dengan motivasi ini tidak akan mengunjungi kawasan dan bangunan bersejarah.

Terakhir adalah wisatawan dengan motivasi fisiologis. Wisatawan ini mengunjungi kawasan dan bangunan bersejarah karena ingin menghilangkan kepenatan dan alasan fotografi. Oleh karena itu sangat berkorelasi dengan faktor kualitas lingkungan dan pengalaman serta aksesibilitas dan keterjangkauan. Kualitas lingkungan yang sakral, bersih, romantis, serta akses menuju kawasan yang mudah menjadikan wisatawan ini datang. Sedangkan faktor sosial dan daya tarik objek tidak menjadi faktor penarik bagi mereka.

Dari hasil analisis korelasi di atas ditemukan kecenderungan hubungan antara faktor pendorong dan faktor penarik yang dapat digambarkan seperti di Gambar 1. 


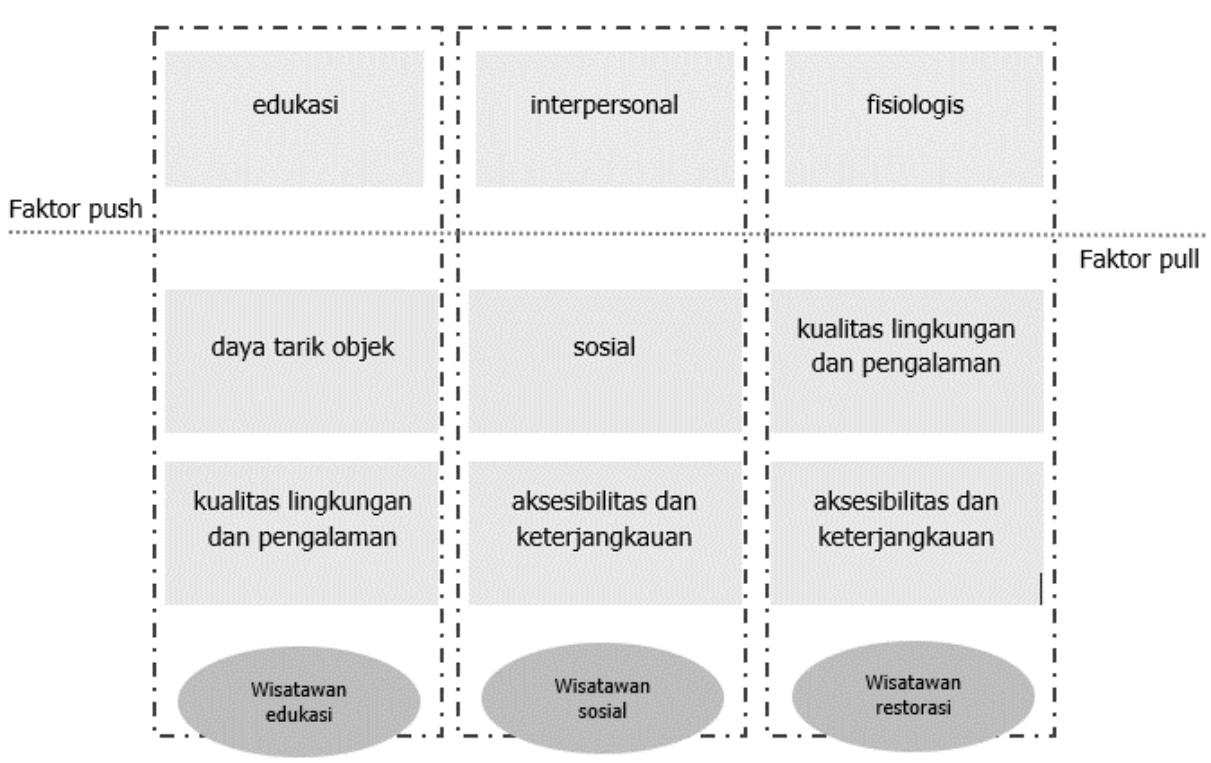

Gambar 1. Diagram Pengelompokan Wisatawan (Sumber: Analisis Peneliti, 2018)

Hubungan antara faktor pendorong dan penarik menghasilkan tiga kelompok wisatawan dalam mengunjungi kawasan dan bangunan bersejarah. Wisatawan edukasi adalah kelompok wisatawan dengan motivasi edukasi. Kelompok ini mengunjungi kawasan dan bangunan bersejarah karena rasa ingin tahu akan sejarah, dan keminatan akan nilai sejarah, sehingga hal yang sangat diperhatikan oleh kelompok ini adalah daya tarik objek dan kualitas lingkungan sebagai faktor penarik. Bangunan yang unik, adanya tour guide, arsitektural bangunan, hingga sakralnya suatu kawasan menjadi faktor penting yang akan mempengaruhi kelompok ini dalam segi edukasi. Wisatawan ini adalah kelompok mayoritas yang mengunjungi kawasan dan bangunan bersejarah.

Wisatawan sosial adalah kelompok wisatawan yang mengunjungi kawasan dan bangunan bersejarah karena ingin memenuhi nilai prestise dalam diri mereka. Wisatawan dengan motivasi ini cenderung hanya ingin terlihat keren di mata sosial, mengikuti acara rohani, hingga keinginan untuk berkontemplasi. Oleh karena itu, dari segi faktor penarik, dimensi sosial dan aksesibilitas adalah yang mendasari wisatawan ini datang. Aksesibilitas yang mudah, harga tiket murah, dan adanya fasilitas umum lainnya menjadi hal yang sangat diperhatikan oleh kelompok ini. Dimensi sosial seperti ajakan keluaraga, dan tugas sekolah atau kantor juga merupakan faktor penarik kelompok ini dalam mengunjungi kawasan dan bangunan bersejarah.

Kelompok yang terakhir adalah wisatawan restorasi yang merupakan kelompok wisawatan dengan motivasi fisiologis. Kelompok ini sangat berkaitan dengan dimensi kualitas lingkungan dan pengalaman serta aksesibilitas dan keterjangkauan sebagai faktor penarik dalam mengunjungi kawasan bangunan besejarah. Wisatawan berkeinginan untuk melakukan fotografi hingga sekedar lepas dari kegiatan sehari-hari. Dalam memenuhi motivasi tersebut, wisatawan ini sangat melihat kualitas lingkungan kawasan dan bangunan bersejarah seperti kesakralan, romantisme bangunan, kebersihan kawasan serta acara 
menarik yang diadakan. Aksesibilitas yang mudah, harga tiket yang murah, hingga fasilitas umum lainnya menjadi faktor pendukung dalam mengunjungi kawasan dan bangunan bersejarah.

\section{Kesimpulan}

Dalam berwisata, masyarakat didasari akan faktor push dan faktor pull. Begitu juga yang terjadi dalam mengunjungi kawasan dan bangunan bersejarah. Hasil dari penelitian mengungkapkan ada tiga dimensi faktor push dan empat dimensi faktor pull. Faktor push yang merupakan motivasi internal terdiri dari dimensi edukasi, interpersonal, dan fisiologis. Faktor pull yaitu faktor lingkungan eksternal adalah aksesibilitas dan keterjangkauan; kualitas lingkungan dan pengalaman; sosial; serta daya tarik objek.

Penelitian ini juga menghasilkan tiga kelompok (wisatawan edukasi, wisatawan sosial, wisatawan restorasi) wisatawan dalam mengunjungi kawasan dan bangunan bersejarah. Kelompok ini dihasilkan berdasarkan korelasi dari faktor push dan faktor pull. Tiap-tiap kelompok memiliki motivasi yang berbeda dengan faktor lingkungan eksternal yang mendukung tiap-tiap motivasi. Wisatawan edukasi adalah kelompok dengan motivasi edukasi yang sangat didukung dengan faktor lingkungan eksternal daya tarik objek dan kualitas lingkungan. Wisatawan sosial merupakan kelompok dengan motivasi interpersonal yang melihat dimensi aksesibilitas dan keterjangkauan serta sosial sebagai faktor pull yang mendukung. Sedangkan kelompok yang terakhir adalah wisatawan restorasi dengan motivasi fisiologis yang didukung dimensi kualitas lingkungan dan pengalaman; serta aksesibilitas dan keterjangkauan sebagai faktor lingkungan eksternal.

Wisatawan edukasi merupakan kelompok mayoritas dalam mengunjungi kawasan dan bangunan bersejarah. Dengan hasil ini, maka diketahui bahwa perkembangan wisata kawasan dan bangunan bersejarah penting memperhatikan kebutuhan dari kelompok ini. Kelompok ini mengunjungi kawasan dan bangunan bersejarah karena didasari keinginan untuk mencari tahu informasi tentang sejarah, dan juga keminatan akan nilai-nilai sejarah. Dengan motivasi tersebut, kelompok ini sangat memperhatikan daya tarik objek wisata dan kualitas lingkungan dan pengalaman. Sehingga nantinya dalam mengembangkan kawasan dan bangunan bersejarah, nilai-nilai edukasi perlu dijadikan acuan. Pemberian fasilitas yang mendukung edukasi bisa ditambahkan dengan memperhatikan pemberian informasi yang lengkap serta adanya fasilitas tour guide dalam kawasan dan bangunan bersejarah.

\section{Daftar Pustaka}

Ardika, I Wayan. (2015). Warisan Budaya Perspektif Masa Kini. Denpasar: Udayana University Press.

Creswell, J.W. (2008). Research Design: Qualitative, Quantitative, and Mixed Methods Approaches. California: Sage Publications, Inc.

Groat, L. \& Wang, D. (2002). Architectural Research Methods. New York: John Wiley \& Sons. Inc.

Hayani. (2007). Motivasi Kunjungan Wisatawan Taman Nasional Gunung Gede Pangrango Di Cibodas. Jakarta: UIN

Henderson, Joan C. (2009). The Meanings, Marketing, and Management of Heritage Tourism in Southeast Asia. Oxon: Routledge 
Inskeep, Edward. (1991). Tourism Planning- An Integrated Sustainable Approach. New York: Van Nostrand Reinhold.

Mohammad, Bashar AMA. (2010). An Analysis of Pull and Push Travel Motivations of Foreign Tourist to Jordan. Malaysia: International Journal of Business and Management Vol. 5, No. 12; December 2010.

Mourato, Susana; Mazzanti, Massimiliano. Economic Valuation of Cultural Heritage: Evidence and Prospects. Los Angeles: The Getty Conservation Institute.

Pendit S Nyoman. (1994). IImu Pariwisata: Sebuah Pengantar Perdana. Jakarta: PT. Pradnya Paramita.

Poria, Y., R. Butler, and D. Airey. (2003). The Core of Heritage Tourism. UK: Annals of Tourism Research, Vol. 30, No. 1, pp. 238-254, 2003.

Sari, Fitria. (2014). Tinjuan Terhadap Motivasi Wisatawan Berkunjung Ke Objek Wisata Air Terjun Aekmartua Kabupaten Rokan Hulu Provinsi Riau. Riau: Jom FISIP Volume 1 No.2

Suarmana, Restu I Wayan dkk. (2017). Pengembangan Pusat Kota Denpasar Sebagai 'Heritage Tourism'. Bali: JUMPA Volume 4 No 1.

Undang-undang Nomor 11 Tahun 2010 tentang Cagar Budaya.

Widiastuti, Eko Heri. (2014). Revitalisasi Benda Cagar Budaya di Kota Semarang. Semarang: Majalah Ilmiah Pawiyatan.

Yoeti, Oka A. (1979). Pemasaran Pariwisata. Bandung: Angkasa. 